\title{
Identifying Potential Hazardous Farms in Nitrate-Vulnerable Water Catchments Based on the Rapid Identification System
}

\author{
Jerzy Mirosław Kupiec* \\ Department of Ecology and Environmental Protection, Poznań University of Life Sciences, Poznań, Poland
}

Received: 29 September 2017

Accepted: 26 November 2017

\begin{abstract}
The aim of this research was the valorization of farms of different types and sizes located in 26 nitrate-vulnerable zones as to their specialization and intensity of production using a comprehensive evaluation method. The analysis was performed using survey data from 2010-2013 covering 164 Polish farms. The quality assessment was divided into two modules: production and environmental. The production module included the share of selected agricultural land and crop groups, consumption of mineral nitrogen and phosphorus fertilizers, consumption of industrial feeds, and the number of animals. The environmental module evaluated term of application of manures to fields, number of days mixed with soil, preparation of silage, management of domestic sewage, storage capacity for manure, and year of construction of plates, tanks, and cesspools. The points earned in individual farms ranged from 52 to 148. Statistical analysis, using the Ward method (Manhattan distance), allowed for seven separate groups of farms. The results showed that such elements as specialization, farm size, share of arable land and grassland, stocking density, mineral fertilizers, and industrial feed consumption were all important for the identification of potential hazardous farms. The average number of points for the individual farm groups ranged from 81 to 120 .
\end{abstract}

Keywords: rapid identification system, comprehensive assessment of farms, non-point pollution, nitrate-vulnerable zones

\section{Introduction}

Council Directive 91/676/EEC of 12 December 1991 [1], which is implemented in Poland, obliges the Member States of the European Union to take measures to prevent dissipation of nitrogen in surface and ground waters. One of the obligatory tasks is the establishment

*e-mail: jerzy.kupiec@up.poznan.pl of sensitive water and nitrate-vulnerable zones (NVZ) in agricultural catchments. In 2013, the European Commission (EC) brought a complaint against Poland to the European Court of Justice (Case C-356/13) [2], in which Poland was accused of failing to reduce emissions of agricultural pollutants. The EC pointed out abuse in the determination of sensitive water and nitrate vulnerable zones and their serious underestimation. In 2012-2016 these areas occupied $4.46 \%$ of Poland. 
Table 1. Characteristics of the analyzed farms.

\begin{tabular}{|c|c|c|c|}
\hline Parameter & Unit & Range & Average \\
\hline Farm area & [ha] & $2-1001$ & 41,9 \\
\hline \multirow{2}{*}{ Arable land } & [ha] & $0,4-870$ & 36,2 \\
\hline & {$[\%]$} & $0-100$ & 85,0 \\
\hline \multirow{2}{*}{ Grassland } & [ha] & $0-55$ & 3,3 \\
\hline & {$[\%]$} & $0-94$ & 10,2 \\
\hline \multirow{2}{*}{ Forests } & [ha] & $0-40$ & 0,7 \\
\hline & {$[\%]$} & $0-50$ & 1,4 \\
\hline \multirow{2}{*}{ Other lands } & [ha] & $0-122$ & 1,6 \\
\hline & {$[\%]$} & $0-60$ & 1,8 \\
\hline \multirow{2}{*}{$\begin{array}{l}\text { Livestock in } \\
\text { total* }\end{array}$} & [LSU] & $0,07-422$ & 50 \\
\hline & {$\left[\mathrm{LSU} \cdot \mathrm{ha}^{-1} \mathrm{UAA}\right]$} & $0,004-17$ & 2,2 \\
\hline \multirow{2}{*}{ Cattle* } & [LSU] & $1-415$ & 37 \\
\hline & {$\left[\mathrm{LSU} \cdot \mathrm{ha}^{-1} \mathrm{UAA}\right]$} & $0,03-11,7$ & 1,4 \\
\hline \multirow{2}{*}{ Pigs* } & [LSU] & $0,4-251$ & 30 \\
\hline & {$\left[\mathrm{LSU} \cdot \mathrm{ha}^{-1} \mathrm{UAA}\right]$} & $0,02-11,7$ & 1,6 \\
\hline \multirow{2}{*}{ Other animals* } & [LSU] & $0,02-48$ & 2 \\
\hline & {$\left[\mathrm{LSU} \cdot \mathrm{ha}^{-1} \mathrm{UAA}\right]$} & $0,002-1,6$ & 0,1 \\
\hline
\end{tabular}

* in farms with livestock; UAA - utilised agricultural area

The current project foresees coverage of almost the entire country with NVZ [3]. The establishment of vulnerable zones involves the imposition of duties and restrictions in agricultural production on all commodity farms. Presently, work on the new Water Law Act [4] is underway. The basis will be the development of one coherent action program for these areas. The primary focus is eliminating mistakes made in agricultural practice. Education in good agricultural practice will also be important for determining the maximum $\mathrm{N}$ rates for individual crops.

The problem of non-point pollution in numerous countries has been present for several decades. The emissions of macronutrients can cause adverse physical, chemical, and biological changes in natural ecosystems [5], hence the importance of monitoring and controlling farms in the context of dissipation of pollutants into the environment. The only available tool for controlling agricultural production is the balance of nutrients [6]. In EU and OECD countries this is obligatory [7-9]. However, the balance of nutrients does not assess all elements of farm and agricultural production as other factors can significantly contribute to the deterioration of water quality. The absence of a comprehensive method for assessing farms in terms of their potential environmental impact, which takes into account several other equally important parameters that may contribute to the deterioration of environmental indicators (aside from the cycle of nutrients), is a problem that should be addressed.

The aim of this research was the valorization of farms of different types and sizes located in 26 nitratevulnerable zones as to their specialization and intensity of production using a comprehensive evaluation method.

\section{Material and Methods}

The analysis was performed using survey data from 2010-2013, which covered 164 farms located in 118 localities, 69 communes, and 5 provinces (Dolnośląskie, Kujawsko-Pomorskie, Łódzkie, Wielkopolskie, Zachodniopomorskie). The farms used in the analyses were active in 26 nitrate-vulnerable zones designated in accordance with the Nitrate Directive EU [1] under which the action program is in force. The average size of the farms was 41.9 hectares. Approximately $22 \%$ of the farms analyzed had no animals. The characteristics of the farms are shown in Table 1. Among farms selected for research, the largest group was medium-sized farms of 11-50 ha (Table 2).

Assessment of potential environmental hazards of the examined farms was performed by the comprehensive method of rapid identification system (RIS) based on basic production and environmental parameters [10]. The selected items were quantified and subjected to point bonitation. The point system was developed so that each farmer could assess their own farm in a relatively uncomplicated manner. The rapid identification system enables identifying farms that may pose a potential threat to the quality of the environment. It can be used as an alternative to the troublesome balance of nutrients that is used to perform monitoring and control of agricultural units and which is often difficult to calculate. The essence of the rapid identification system is the production and environmental modules (Fig. 1).

\section{Production Module}

The production module includes elements directly linked to the production process, i.e., with plant and animal production:

a) Share of arable land and grassland (\%).

b) Share of selected groups of crops that have the greatest degree of influence on reproduction or

Table 2. Division of surveyed farms into area groups.

\begin{tabular}{|c|c|c|c|c|c|c|}
\hline Range [ha] & $\leq 10$ & $11-20$ & $21-50$ & $51-100$ & $100-200$ & $>200$ \\
\hline Share of farms [\%] & 7 & 49 & 31 & 9 & 2 & 2 \\
\hline
\end{tabular}


degradation of organic matter in soil (cereals, industrial plants, vegetable, intensive orchards, small-seeded papilionaceae, leguminous, pasture crops, and green manure) (\%).

c) Livestock were calculated based on the Regulation of 2010 [11] (LSU·ha-1 UAA).

d) Consumption of nitrogen and phosphorous fertilizers ( $k g ~ N$ and $\left.\mathrm{P} \cdot \mathrm{ha}^{-1} \mathrm{UAA}\right)$.

e) Use of industrial feeds, calculated based on nitrogen equivalent (0.043) - average nitrogen content in industrial feeds most frequently recorded on farms [12]:

$$
\mathrm{Npp}=\Sigma \mathrm{pp} \times 0.043
$$

...where:

$\mathrm{Npp}$ - nitrogen in industrial feeds

$\Sigma p p$ - industrial feeds in total

The sum of nitrogen in the feeds was converted into area of agricultural land ( $\left.\mathrm{kg} \mathrm{N} \cdot \mathrm{ha}^{-1} \mathrm{UAA}\right)$.

\section{Environmental Module}

The environmental module is based on practices related to the organizational sphere and farm management (Fig. 1) calculated by:

a) Date of application of solid and liquid manures on fields - information provided by the farmers (monthly).

b) Shortages of storage capacity for solid and liquid manures were calculated according to the formula:

$$
B_{b}=Z-S
$$

...where:

$\mathrm{B}_{\mathrm{b}}$ - shortages of buildings

$\mathrm{Z}$ - demand for: plates $\left(\mathrm{m}^{2}\right)$ or tanks $\left(\mathrm{m}^{3}\right)$

$\mathrm{S}$ - current state: plates $\left(\mathrm{m}^{2}\right)$ or tanks $\left(\mathrm{m}^{3}\right)$

The demand for buildings used to store manures was calculated based on the average annual livestock conditions [13]. A 5\% tolerance threshold was applied due to changes in livestock over the year (animal deaths, births, sales, purchases). The construction deficiencies were converted to percentages and the scoring system was given according to the range:

c) Year of construction,

d) Period manures were applied for plowing (number of days).

e) Facilities for silage preparation - variants: concrete floor with drainage tank, foil sleeves, concrete floor without drainage tank, ground isolated with foil, ground without isolation.

f) Manner of domestic waste water management variants: domestic wastewater treatment plants, sewage system, public waste water treatment plant or reception by municipal services, agricultural use.

For the production module, the number of possible points for each parameter ranged from 0 to 16 and for the environmental module from 0 to 11 . Scoring

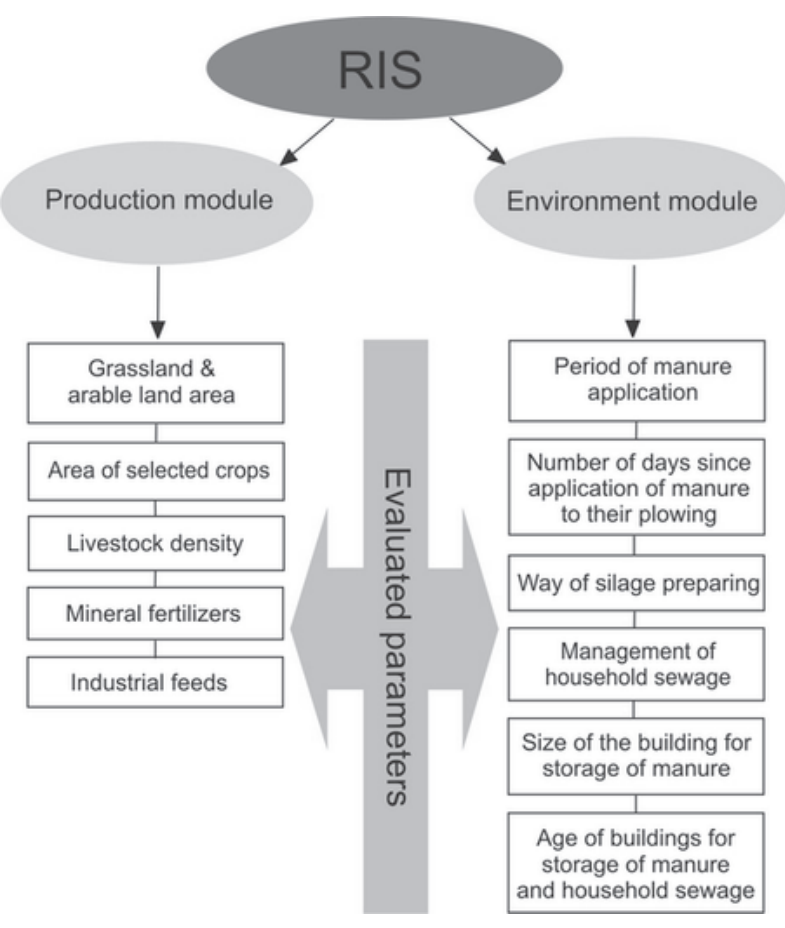

Fig. 1. Construction of the rapid identification system.

the assessed features depended on the degree of differentiation. A less varied parameter is characterized by a smaller range of points. The degree of danger increases as the number of points increases, which is related to a higher risk of nutrient dispersion in the environment due to improper farming practices. At the present stage of the study, it can be assumed that farms that received more than 120 RIS points pose a definite environmental risk, and that agricultural complexes within the range of 101-120 RIS points should be subject to ad hoc controls as farms that may pose environmental risks.

\section{Results and Discussion}

The total number of points awarded individual farms ranged from 52 to 148 (average 98). Differences within the individual modules were: production module 49-109 (average 71), and environmental module 0-60 (average 27). The largest number of points accumulated was mainly by pig farms, which indicates a potentially greater risk of exceeding the environmental standards in this particular group of farms (Table 3). As can be seen in Table 6, the smallest amounts were received from farms without animals.

All examined farm features were subjected to statistical analysis by the Ward method of cluster analysis (Manhattan city distance) using Statistica version 13.1 software. This allowed for distinguishing seven distinct groups.

The farms that received the highest scores (100 points and more: A, B, C, D) are highly intensive farms, as seen by consumption of inputs such as 
Table 3. Score assessment according to specialization group.

\begin{tabular}{|c|c|c|c|c|c|c|c|c|}
\hline \multirow{2}{*}{ The score range } & \multirow{2}{*}{ The share of farms [\%] } & \multicolumn{6}{|c|}{ The share of specialization groups [\%] } \\
\cline { 3 - 9 } & & $\mathrm{F}$ & $\mathrm{F}<0,15$ & $\mathrm{CF}$ & $\mathrm{SF}$ & $\mathrm{CF} / \mathrm{SF}$ & $\mathrm{SF} / \mathrm{CF}$ & $\mathrm{PF}$ \\
\hline$<60$ & 4 & $\mathbf{1 0 0}$ & 0 & 0 & 0 & 0 & 0 & 0 \\
\hline $61-80$ & 15 & $\mathbf{7 6}$ & 4 & 8 & 0 & 8 & 4 & 0 \\
\hline $81-100$ & 37 & 16 & 2 & $\mathbf{3 0}$ & 23 & 16 & 11 & 2 \\
\hline $101-120$ & 30 & 0 & 2 & $\mathbf{3 9}$ & $\mathbf{3 5}$ & 14 & 10 & 0 \\
\hline$>120$ & 14 & 0 & 0 & 30 & $\mathbf{5 8}$ & 4 & 4 & 4 \\
\hline
\end{tabular}

$\mathrm{F}$ - farms without animals, $\mathrm{F}<0.15$ - farms with livestock density below $0.15 \mathrm{LSU} \cdot \mathrm{ha}^{-1}$, CF - farms only with cattle, SF - farms only with pigs, $\mathrm{CF} / \mathrm{SF}$ - farms with cattle $>50 \%$ of share and with pigs $>30 \%$ of share, $\mathrm{SF} / \mathrm{CF}$ - farms with pigs $>50 \%$ of share and with cattle $>30 \%$ of share, $\mathrm{PF}$ - farms only with poultry.

mineral fertilizers and industrial feeds (Table 4). Farms in group $\mathrm{B}$ are those that did not purchase mineral fertilizers during the examined period, but had a high consumption of industrial feeds. These were the smallest farms, specializing mainly in fattening pigs (Table 5). They also had the highest livestock density ( $>7$ LSU $\cdot$ ha $^{-1}$ UAA). All A-D farms exceeded the recommended 1.5 LSU $\cdot \mathrm{ha}^{-1}$ UAA standard. Group A was characterized by the highest mineral fertilization. This group was composed of farms without animals (50\%). In such farms, most often the lack of manure was compensated by mineral fertilizers.

The farms in group E received the lowest score (Table 4). They were also the most diversified in terms of specialization (Table 5). Use of mineral fertilizers on these farms was the lowest, as was their consumption of industrial feeds. Farms in group F differed from the other farms by size and also by lowest livestock density. This group was dominated by cattle farms (Table 5). The consumption of nitrogenous fertilizers and industrial feeds was also low (Table 4). In all groups of farms, except for $\mathrm{B}$ and $\mathrm{E}$, the use of nitrogenous fertilizers calculated by the gross nitrogen balance was higher than the average for Poland, but also much higher than the average for the EU-27 [14]. A similar situation was also observed for the case of phosphorus [15].

The infrastructure for the storage of manures and domestic waste water showed some variation in specific groups of farms. The biggest deficiencies in buildings were recorded in groups A-D (Table 6). The deficiencies concerned both manure plates and tanks for liquid manures. The average age of plates in individual groups was not highly variable. In groups $\mathrm{B}, \mathrm{D}$, and $\mathrm{F}$ the plates were built after Poland's accession to the EU in 2004. In other cases, apart from Group A, where no plates were recorded, the constructions were built in the preaccession period, but after the year 2000. In the case of liquid manure tanks, the vast majority of construction came from the second half of the 1990s. The average age of cesspools ranged from the second half of the ' $80 \mathrm{~s}$ to the first half of the '90s (Table 6).

The periods of application of solid manure did not differ significantly between groups B, C, D, E, and G (Fig. 3). More farmers fertilized the fields in April in group B. The preferred period in farms within groups A and $\mathrm{F}$ was from August to October.

In the case of the application of liquid manure, the farmer's preferences for spring were almost identical in most of the analyzed groups (Fig. 4). The visible

Table 4. Differences between separated groups of farms on the basis of the most discriminating features and the results of point bonitation in farms.

\begin{tabular}{|c|c|c|c|c|c|c|c|c|}
\hline \multirow{2}{*}{ Group } & Farm area & Arable land & Grasslands & $\mathrm{N} \min ^{1}$ & $\mathrm{P} \min ^{2}$ & $\mathrm{~N}$ of feed ${ }^{3}$ & \multirow{2}{*}{$\begin{array}{c}\text { The livestock density } \\
{\left[\mathrm{LSU} \cdot \mathrm{ha}^{-1} \mathrm{UAA}\right]}\end{array}$} & \multirow{2}{*}{$\begin{array}{c}\text { Rapid identification system } \\
\text { on average }\end{array}$} \\
\hline & [ha] & \multicolumn{2}{|c|}{$[\%]$} & \multicolumn{3}{|c|}{$\left[\mathrm{kg} \cdot \mathrm{ha}^{-1} \mathrm{UAA}\right]$} & & \\
\hline A & 23.6 & 91.9 & 6.0 & 192 & 31 & 109 & 4.6 & 100 \\
\hline B & 19.0 & 91.7 & 7.4 & 0 & 0 & 1527 & 7.3 & 115 \\
\hline $\mathrm{C}$ & 21.1 & 81.3 & 11.6 & 178 & 26 & 24 & 1.8 & 110 \\
\hline $\mathrm{D}$ & 23.9 & 91.6 & 6.2 & 114 & 12 & 319 & 3.6 & 120 \\
\hline $\mathrm{E}$ & 29.3 & 84.7 & 9.0 & 4 & 1 & 31 & 1.3 & 81 \\
\hline $\mathrm{F}$ & 889.3 & 89.8 & 4.7 & 49 & 15 & 32 & 0.3 & 91 \\
\hline G & 31.8 & 84.4 & 12.6 & 117 & 17 & 23 & 0.9 & 91 \\
\hline
\end{tabular}

\footnotetext{
${ }^{1}$ nitrogen from mineral fertilizers, ${ }^{2}$ phosphorus from mineral fertilizers, ${ }^{3}$ nitrogen from industrial feed
} 
Table 5. Distribution between groups of farms based on specialization of production.

\begin{tabular}{|c|c|c|c|c|c|c|c|}
\hline \multirow{2}{*}{ Group } & \multicolumn{7}{|c|}{ Share of specialization groups $[\%]^{*}$} \\
\hline & $\mathrm{F}$ & $\mathrm{F}<0,15$ & $\mathrm{CF}$ & SF & $\mathrm{CF} / \mathrm{SF}$ & $\mathrm{SF} / \mathrm{CF}$ & $\mathrm{PF}$ \\
\hline A & 50 & 0 & 25 & 0 & 25 & 0 & 0 \\
\hline B & 34 & 0 & 0 & 66 & 0 & 0 & 0 \\
\hline $\mathrm{C}$ & 1 & 4 & 31 & 33 & 12 & 19 & 0 \\
\hline D & 0 & 0 & 32 & 56 & 0 & 6 & 6 \\
\hline E & 36 & 0 & 20 & 22 & 14 & 6 & 2 \\
\hline F & 33 & 0 & 67 & 0 & 0 & 0 & 0 \\
\hline G & 35 & 0 & 35 & 11 & 16 & 0 & 3 \\
\hline
\end{tabular}

* the abbreviations are explained under the table 3

differences were recorded for groups $\mathrm{A}, \mathrm{B}$, and $\mathrm{F}$. The farms in these groups preferred late summer and autumn seasons.

Comprehensive approaches to assess farms in terms of their impact on the ecosystem are justified in the context of conservation of natural resources and raising environmental standards in agricultural enterprises. Officially, these include: implementing the assumptions of the Nitrates Directive (91/676/ EEC) [1], the Water Framework Directive (2000/60/ EC) [16], and the Sewage Sludge Directive (86/278/ EEC) [17], as well as the obligations arising from Polish membership in the Organization for Economic Co-operation and Development (OECD) and the Baltic Marine Environment Protection Commission - Helsinki Commission (HELCOM), which are sustainable development principles and requirements that Poland is expected to consistently implement.

The rapid identification system is focused primarily on the aspects of nutrient dissipation, as this is the prime problem in the area of agricultural production [18-22]. It incorporates all elements prioritized by action programs for nitrate-vulnerable zones. It can also be

Table 6. Characteristics of infrastructure.

\begin{tabular}{|c|c|c|c|c|c|}
\hline \multirow{3}{*}{ Group } & \multicolumn{2}{|c|}{ Shortages } & \multicolumn{3}{|c|}{ Age of construction } \\
\hline & $\begin{array}{c}\text { Concrete } \\
\text { plate }\end{array}$ & Tank & $\begin{array}{c}\text { Concrete } \\
\text { plate }\end{array}$ & Tank & Cesspool \\
\hline & \multicolumn{2}{|c|}{ [\%] } & \multicolumn{3}{|c|}{ [year] } \\
\hline A & 25 & 25 & lack & 1997 & 1993 \\
\hline B & 67 & 57 & 2005 & 1998 & 1986 \\
\hline $\mathrm{C}$ & 66 & 69 & 2003 & 1994 & 1990 \\
\hline $\mathrm{D}$ & 33 & 52 & 2005 & 2000 & 1986 \\
\hline $\mathrm{E}$ & 10 & 27 & 2001 & 1999 & 1987 \\
\hline $\mathrm{F}$ & 4 & 4 & 2006 & 1986 & 1993 \\
\hline G & 6 & 2 & 2003 & 1998 & 1991 \\
\hline
\end{tabular}

used to identify farms that have a particularly negative impact on the quality of the environment. Products high in nitrogen and phosphorus used in plant and animal production are of particular importance in the agroenvironmental context, as these two macronutrients have the greatest adverse impact on changes occurring in natural ecosystems. Some authors claim that to avoid these risks the agro-ecosystem should be sealed [23]. When properly managed, agro-ecosystems can improve the biological properties and composition of plant products [24]. It is important to remember that biogenic substances are released by production, management, and storage of wastewater in the farm, as well as from buildings used to store animal excrement and silage preparation [25-27].

Numerous detailed analyses have confirmed that farms with livestock production pose higher risks. Such farms received significantly more points with the rapid identification system, which also confirms its effectiveness in typifying farms that may have a negative impact on the environment. The results have shown that that especially pig farms pose a high risk. According to some authors, the negative impact of raising pigs on adjoining areas results primarily from the production of manure, but also causes emissions of ammonia, methane, carbon dioxide, nitrogen oxides, and hydrogen sulphide [28-33].

The agricultural enterprises without animals also can pose a threat, mainly related to the production module. In the environmental module, such farms are practically excluded from the management of manure due to lack of livestock. Only in the case of their purchase is the application term on the field and the period from application to plowing included. However, the purchase of manure by farms without animals was rarely recorded. An additional parameter in the environmental module evaluated in the farms without animals was the management of domestic wastewater. There are still cases of agricultural use of raw domestic sewage, which can obviously be a serious threat to the quality of water. Domestic wastewater often includes a number 


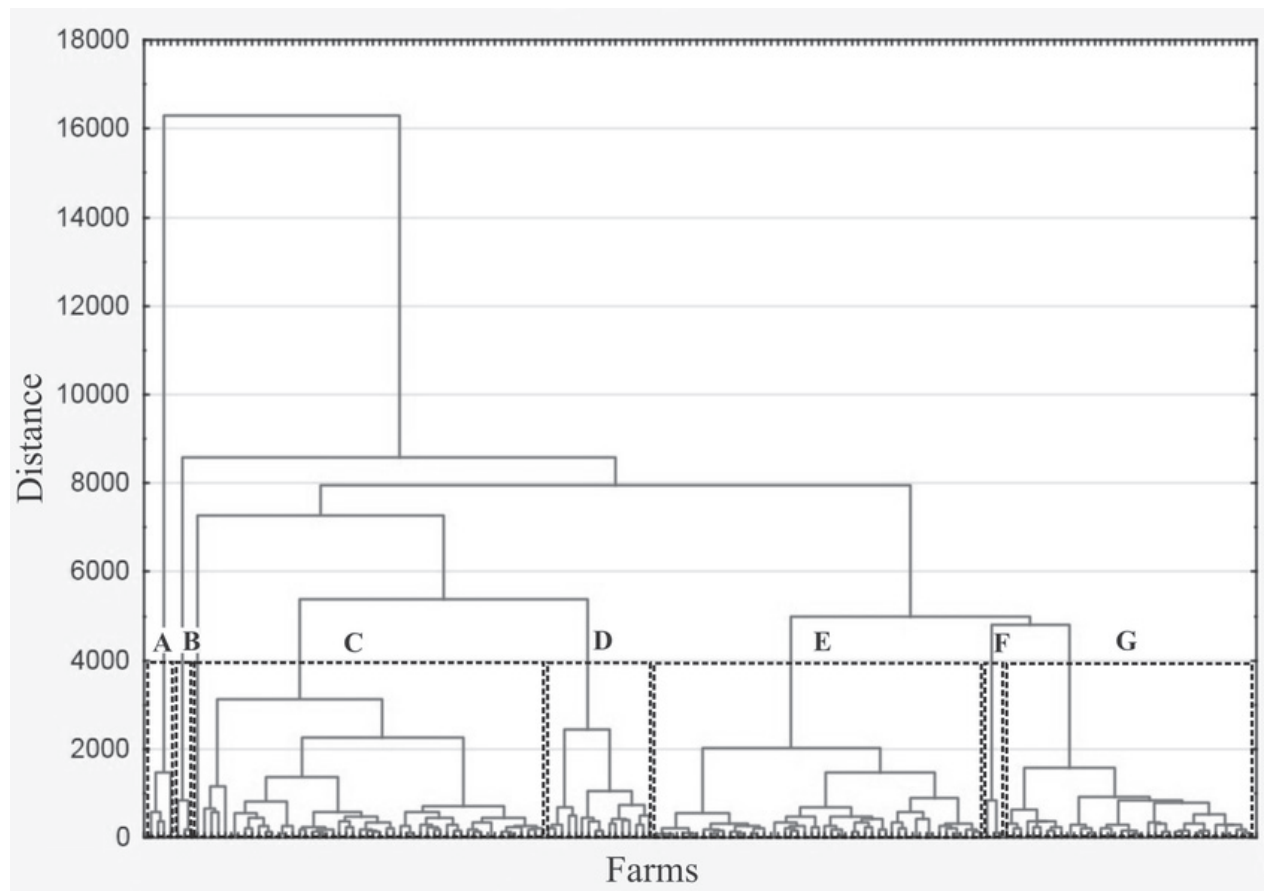

Fig. 2. Dendrogram (hierarchical tree) for the analyzed farm features made by the Ward method of urban distance (Manhattan).

of organic and inorganic pollutants, including biogenic, specific, heavy metal, and biological contaminants [34]. The conditions of correct use of agricultural wastewater are defined by the Water Law Act [4], Regulation of the Minister of the Environment 2006 [35], and the Code of Good Agricultural Practice [36]. Among the surveyed farms, $16 \%$ poured raw sewage on fields.

A very important element in animal production is industrial feeds. In the last dozen or so years, there have been major changes in this respect. Feeds produced on farms are increasingly being replaced by industrially produced feeds. Their high price is compensated by higher feed value due to the high concentration of nutrients. In Poland, the production of industrial feeds shows an upward trend. Their production in the years 2000-2014 increased almost $101 \%$. Breeding of swine is second only after poultry

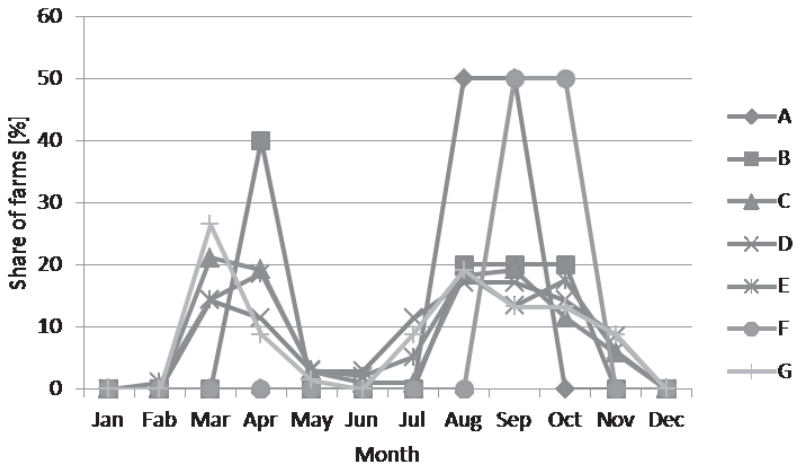

Fig. 3. Dates of application of solid manure on fields in particular groups of farms. production in terms of consumption of this type of feed [37]. This is confirmed by the results of this study, which show very high consumption of industrial feeds in pig agricultural enterprises. The vast majority of the analyzed farms came from Wielkopolska Province, where the share of pig farms was significant.

The consumption of nitrogenous fertilizers in the analyzed farms was very high. Groups A, C, D, and $G$ oftentimes significantly exceeded the average values given by the Central Statistical Office of Poland for the years 2006-2016 (65-81 kg N·ha ${ }^{-1}$ UAA). Likewise, the situation was the same with phosphorus. The average consumption of this component in the years 2006-2016 in the country ranged from 9 to $12 \mathrm{~kg} \mathrm{P} \cdot \mathrm{ha}^{-1}$ UAA [38]. Consumption of mineral fertilizers in EU-28 in 2015 amounted to $74.4 \mathrm{~kg} \mathrm{~N}$ and $7.4 \mathrm{~kg} \mathrm{P}$ per hectare UAA [39]. No mineral fertilization was recorded in

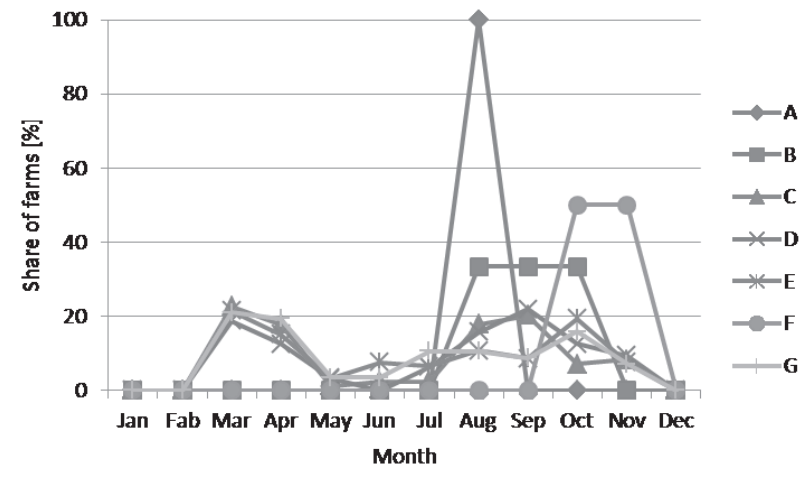

Fig. 4. Periods of application of liquid manure on fields in particular groups of farms. 
the farms with the smallest areas in group B. In group E mineral fertilization was marginal.

\section{Conclusions}

1. A detailed analysis of selected farms has shown that farms with high livestock density have the most severe problem in the context of poor farming practices and potential environmental impact. Livestock production increased with production intensification as can be seen from the use of mineral fertilizers or industrial feeds. These farms received high scores according to the comprehensive assessment of the rapid identification system.

2. The studies have shown that farms with small areas may pose a greater threat to the quality of natural ecosystems than large farms. Some of these farms, such as the smaller animal farms, thrive by intensive livestock production (cattle farms, poultry farms, pig farms, etc.). The conducted analyses showed that industrial feed consumption can be as much as 66 times higher compared to farms with the lowest consumption ratio. Farms with the highest feed consumption received the highest number of RIS points.

3. The greatest shortcomings of storage capacity for manure were recorded on farms with high livestock density, exceeding the recommended 1.5 LSU $\cdot \mathrm{ha}^{-1}$ UAA. The high intensity of production, the high cost of construction of such buildings, often lack of enough space, but also constantly changing legal regulations and recommendations in this area could affect such conditions.

4. In the case of the period of manure application on fields, it can be noted that almost all farms have banned their use in the period from December to February. However, most of the analyzed groups chose summer and late summer periods. They are not prohibited, but are not recommended, due to the possibility of loss of nutrients resulting from faster biomass mineralization and lack of plants in the field during these periods. Also, the increased humidity in the soil can exacerbate the loss of nutrients to the environment.

5. Studies have shown that the rapid identification system allows the selection of farms that may have potentially negative impacts on the environment, including water quality. The farms with high consumption of selected means of production and those using inadequate agricultural practices received the highest number of points.

\section{Acknowledgements}

This research was partially financed by the National Science Centre Research (Poland), project No. N N305 372238 .

\section{Conflict of Interest}

The authors declare no conflict of interest.

\section{References}

1. Council Directive 91/676/EEC of 12 December 1991 concerning the protection of waters against pollution caused by nitrates from agricultural sources. Official Journal L 375, 31/12/1991, P. 0001 - 0008.

2. Failure of a Member State to fulfill obligations - Directive 91/676/EEC - Protection of waters against pollution caused by nitrates from agricultural sources - Inadequate definition of waters which are polluted or are vulnerable to pollution - Inadequate classification of vulnerable zones - Action programs - Deficient measures. Judgment of the Court (Ninth Chamber) of 20 November 2014. European Commission v Republic of Poland. Case C-356/13 http:// curia.europa.eu/juris/document/document.jsf?text $=\&$ doci $\mathrm{d}=159825$ \& pageInde $=0$ \& doclang $=$ pl\&mode $=$ req \& $\operatorname{dir}=\&$ occ $=$ first \& part $=1 \&$ cid $=549841$. 2014. [access 05.07.2017]

3. National Water Management Authority. New list of sensitive waters to pollution of nitrogen compounds from agricultural sources and vulnerable areas - NVZ's. http:// www.kzgw.gov.pl/index.php/pl/aktualnosci/270-nowywykaz-wod-wrazliwych-na-zanieczyszczenie-zwiazkamiazotu-ze-zrodel-rolniczych-oraz-obszarow-szczegolnienarazonych-osn. 2017. [access 05.07.2017] [In Polish]

4. Water Law Act of July 18, 2001 (Journal of Laws of 2001, No. 115, item 1229). 2001 [In Polish].

5. WIORA J., KOZYRA A. WIORA A. Towards automation of measurement processes of surface water parameters by a remote-controlled catamaran. Bull. Pol. Ac.: Tech. 65 (3), 351, 2017.

6. KUPIEC J.M. A review of methods for NPK balancing in agricultural production. Inżynieria i Ochrona Środowiska. 8, 3, 323, 2015 [In Polish].

7. Regulation of the Minister of Environment of 23 December 2002 on the detailed requirements to be met by the programs of measures aimed at reducing the outflow of nitrogen from agricultural sources (Journal of Laws from $2003 \mathrm{nr}$ 4, item 44). 2003 [In Polish].

8. KOPIŃSKI J. Regional diversification of nitrogen, phosphorus and potassium balance in Polish agriculture in 1999-2003. [In:] Nawozy i nawożenie. [Ed.] Lipiński W., Fotyma M., IUNG, Puławy, 2 (23), 84, 2005 [In Polish].

9. GAJ R., BELLALOUI N. Evaluation of phosphorus and nitrogen balances as an indicator for the impact of agriculture on environment: A comparison of a case study from Poland and Mississippi US. Agricultural Sciences. 3, 2, 317, 2012.

10. KUPIEC J.M. Assessment of potential threats to the environment from selected farms using the rapid identification system. [In]: Agriculture of XXI century - problems and challenges. (Ed.) Łuczycka D. Idea Knowledge Future. Wrocław: 396, 2017 [In Polish].

11. Regulation of the Council of Ministers of November 9, 2010 on types of projects that may have a significant impact on the environment (Journal of Laws from 2010, No 2013 item. 1397). 2010 [In Polish].

12. KUPIEC J. Assessment of the nutrient balance (NPK) as a basis for monitoring agricultural production in the aspect of environmental protection. Ph.D. thesis, Poznan University of Life Sciences. 2008 [In Polish]. 
13. Regulation of the Council of Ministers of 18 January 2005 on the detailed conditions and procedures for granting financial assistance for the adaptation of agricultural holdings to EU standards covered by the rural development plan (Journal of Laws 2005, No. 17 item 142). 2005 [In Polish].

14. EUROSTAT. Statistic Explained. Nitrogen balance in agriculture. http://ec.europa.eu/eurostat/statisticsexplained/index.php/Agri-environmental indicator mineral fertiliser consumption. 2017. [access 08.11.2017]

15. EUROSTAT. Statistic Explained. Phosphorus balance in agriculture. http://ec.europa.eu/eurostat/statisticsexplained/index.php/Archive:Phosphorus_balance_in agriculture. 2017. [access 08.11.2017]

16. Directive 2000/60/EC of the European Parliament and of the Council of 23 October 2000 establishing a framework for Community action in the field of water policy. Official Journal L 327, 22/12/2000 P. 0001 - 0073.

17. Council Directive 86/278/EEC of 12 June 1986 on the protection of the environment, and in particular of the soil, when sewage sludge is used in agriculture. Official Journal L 181, 04/07/1986 P. 0006 - 0012.

18. DIETZ F.J., VOLLEBERGH H., DE VRIES J.L. Environment, Incentives and the Common Market. Springer Science \& Business Media. 4, 179, 2012.

19. IKENBERRY C.D., SOUPIR M.L., SCHILLING K.E., JONES C.S., SEEMAN A. Nitrate-nitrogen export: Magnitude and patterns from drainage districts to downstream river basins. Journal of Environmental Quality 43, 2024, 2014.

20. LAITOS J.G., RUCKRIEGLE H. The Clean Water Act and the challenge of agricultural pollution. Vermont Law Review 37, 1032, 2013.

21. BILLEN G., GARNIER J., LASSALETTA L. The nitrogen cascade from agricultural soils to the sea: modelling nitrogen transfers at regional watershed and global scales. Phil Trans R Soc B. 368: 20130123. http:// dx.doi.org/10.1098/rstb.2013.0123. 2013.

22. KOPIŃSKI J., JURGA B. Managing Phosphorus in Polish Agriculture - Production and Environmental Aspects. Pol. J. Environ. Stud. 25, 6, 2461, 2016.

23. SOSULSKI T., ŁABĘTOWICZ J. Estimation of dissipation of nitrogen from Polish agriculture into the atmosphere and surface and ground waters. Postępy Nauk Rolniczych. 5, 3, 2007 [In Polish].

24. BRANDT K., LEIFERT C., SANDERSON R., SEAL C.J. Agroecosystem Management and Nutritional Quality of Plant Foods: The Case of Organic Fruits and Vegetables. Critical Reviews in Plant Science. 30 (1-2), 177, 2011.

25. MYCZKO A., LENARCZYK J., RUDNIK K. Methods of storing manures on farms. Woda-Środowisko-Obszary Wiejskie. 9, 1 (25), 39, 2009 [In Polish].

26. The Agricultural Advisory Centre in Brwinów. Adaptation of the farm to the minimum cross compliance requirements and to health and safety at work. http://www.cdr.gov.pl/ pol/do_pobrania/poradnik_metodyczny.pdf. 2012. [access 13.04.2017] [In Polish].
27. KUPIEC J.M., OLISKIEWICZ-KRZYWICKA A., STACHOWSKI P. Evaluation of selected elements of water and sewage management and loading of agricultural land with macroelements from household sewage in selected farms of Wielkopolska. Annual Set The Environment Protection: 17, 1017, 2015 [In Polish].

28. HOLLY M.A., LARSON R.A., POWELL M. J., RUARK M.D., AGUIRRE-VILLEGAS H. Greenhouse gas and ammonia emissions from digested and separated dairy manure during storage and after land application. Agriculture, Ecosystems \& Environment. 5, 239, 410, 2017.

29. MARSZAŁEK M., BANACH M., KOWALSKI Z. Impact of slurry on the environment - potential hazards. J. Ecol. Health. 15, 2: 66, 2011 [In Polish].

30. IMBEAH M. Composting piggery waste: A review. Bioresource Technology. 63, 197, 1998.

31. TOFANT A., PAVICIĆ Z., MATKOVIĆ K. HADINA S., KRIŽANIĆ J. Pig slurry hygienization with hydrogen peroxide-silver complex an environmentally acceptable disinfectant. Veterinarski Archiv. 73 (6), 345, 2003.

32. HOBBS P.J., PAIN B.F., KAY R.M., LEE P.A. Reduction of odorous compounds in fresh pig slurry by dietary control of crude protein. J. Sci. Food Agr. 71, 508, 1996.

33. RZEŹNIK W., MILECAREK P. Greenhouse Gases and Ammonia Emission Factors from Livestock Buildings for Pigs and Dairy Cows. Pol. J. Environ. Stud. 25 (5), 1813, 2016.

34. KIRCHMANN H., BÖRJESSON G., KÄTTERER T., COHEN Y. From agricultural use of sewage sludge to nutrient extraction: A soil science outlook. Ambio. 46 (2), 143, 2017.

35. Regulation of the Minister of the Environment of 24 July 2006 on the conditions to be met for the introduction of sewage into waters or to land and on substances particularly harmful to the aquatic environment (Journal of Laws No. 137, item 984, as amended). 2006 [In Polish].

36. Code of Good Agricultural Practice. Ministry of Agriculture and Rural Development, Ministry of the Environment. (Ed.) Duer I., Fotyma M., Madej A. 93. 2004 [In Polish].

37. URBAN S. Changes in feed production in Poland. Stowarzyszenie Ekonomistów Rolnictwa i Agrobiznesu. Roczniki Naukowe. 12 (5), 307, 2015 [In Polish].

38. Central Statistical Office of Poland. The means of production in agriculture in the marketing year 2015/2016. http://stat.gov.pl/obszary-tematyczne/rolnictwolesnictwo/rolnictwo/srodki-produkcji-w-rolnictwie-wroku-gospodarczym-20152016,6,13.html. 2017. [access 15.03.2017] [In Polish].

39. EUROSTAT. Statistic Explained. Agri-environmental indicator - mineral fertilizer consumption. http:// ec.europa.eu/eurostat/statistics-explained/index.php/ Agri-environmental_indicator_-_mineral_fertiliser_ consumption. 2017. [access 20.09.2017] 